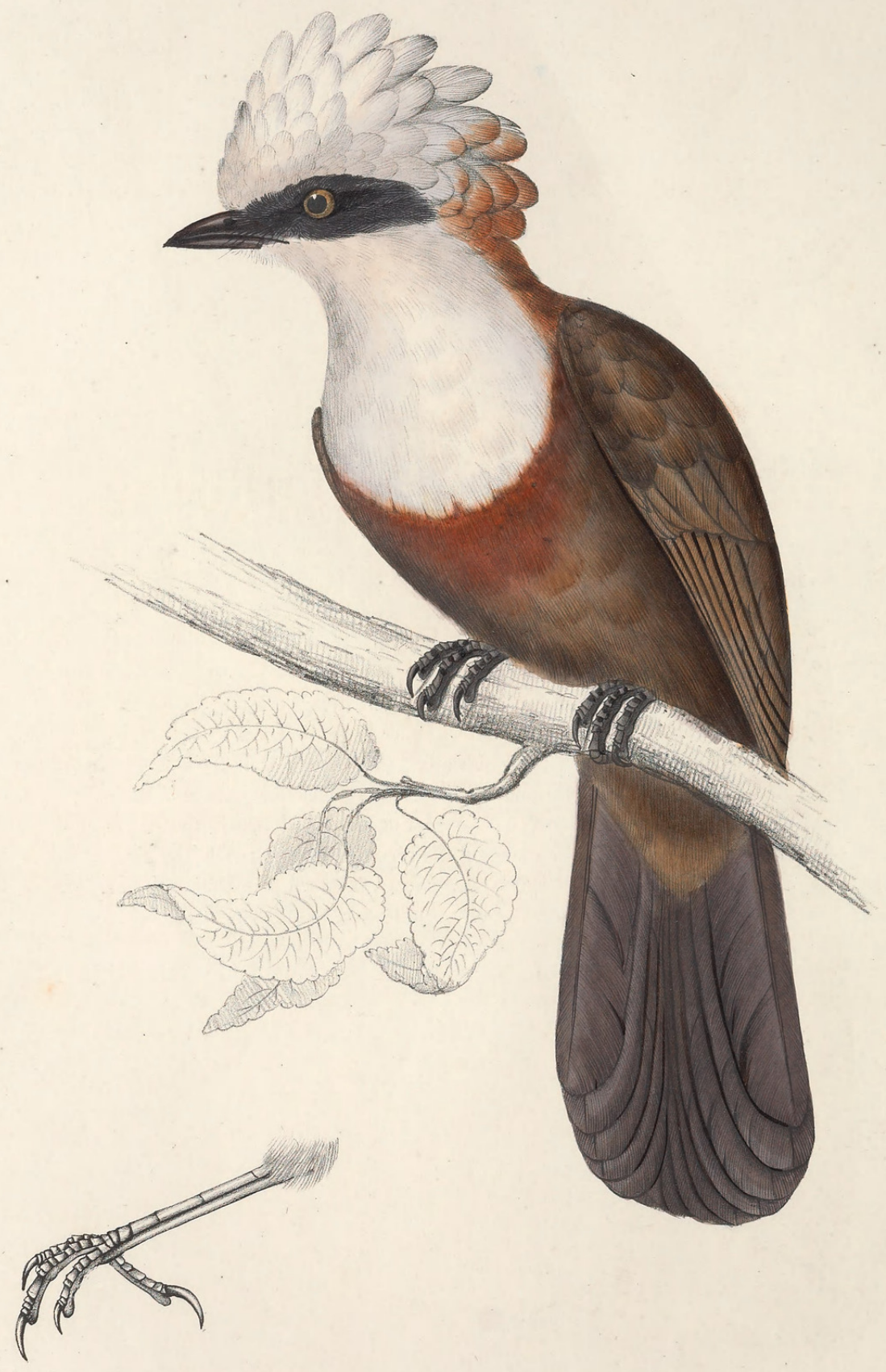

$\mathbb{G} A \mathbb{R} U \mathbb{L}_{A} \mathbb{S} \quad \mathbb{L}_{A} \mathbb{U} \mathbb{C} \mathbb{D} I_{A} \mathbb{P} \mathbb{H} \mathbb{U}$. 
TAB. XVIII.

\section{CINCLOSOMA LEUCOLOPHUM.}

THIs interesting bird has hitherto been but little seen in collections. It is a species having many synonyms, and almost as many generic appellations; and in adding that of Cinclosoma, we consider ourselves borne out by its strong resemblance in form and other essential characteristics to the various species of that genus.

General Hardwicke informs us that it is known in India by the name of Rawil-Khuy, or Rawil Kuhy ;by the English residents it is called the Laughing. Crow, from the circumstance of these birds assembling in numbers of twenty to fifty, and making a noise closely resembling many persons laughing together. It is common in the forests between Hurdwar and Sireenagur, and feeds on the fruits there met with.

The plumage of the back, wings, and sides is olive-brown; on the tail the brown is that of umber: the head is ornamented with an elevated crest of rounded feathers; a black line passes from the base of the beak through the eyes, and occupies the ear-coverts :-excepting this black mark, the whole of the head is white, as are also the throat and breast; the feathers of the crest as they approach the occiput appear as if slightly washed with Indian ink; the whole of this white space is bounded by a band of rufous, broad at the back of the neck, narrower down the sides, and broad on the breast, which loses itself in the olive brown of the rest of the body; beak and tarsi black.

Total length, 11 inches; wings, $5 \frac{1}{4}$; beak, $1 \frac{1}{8}$; tarsi, $1 \frac{3}{4}$; tail, $7 \frac{1}{4}$. 


\section{$2 \mathrm{BHL}$ Biodiversity Heritage Library}

Gould, John. 1831. "Cinclosoma leucolophum [Tab. XVIII]." A century of birds from the Himalaya Mountains -. https://doi.org/10.5962/p.323524.

View This Item Online: https://www.biodiversitylibrary.org/item/132967

DOI: https://doi.org/10.5962/p.323524

Permalink: https://www.biodiversitylibrary.org/partpdf/323524

\section{Holding Institution}

Smithsonian Libraries

\section{Sponsored by}

Biodiversity Heritage Library

\section{Copyright \& Reuse}

Copyright Status: Public domain. The BHL considers that this work is no longer under copyright protection.

This document was created from content at the Biodiversity Heritage Library, the world's largest open access digital library for biodiversity literature and archives. Visit BHL at https://www.biodiversitylibrary.org. 